\title{
Brand Equity in Frito Lay Chips: An Exploratory Research on Turkish Young Consumers in Covid-19 Days
}

\author{
Begüm Şahin \\ Asst. Prof., OSTIMM Technical University \\ Faculty of Economics and Administrative Sciences \\ International Trade and Finance Department \\ Address: OSTIM, 06374 Ankara \\ TURKEY \\ Egehan Özkan \\ Lecturer (PhDc), OSTIMM Technical University \\ Vocational School of Higher Education \\ Logistics Program \\ Seray Yeşilırmak \\ Res. Asst., OSTIMM Technical University \\ Faculty of Economics and Administrative Sciences \\ International Trade and Finance Department
}

\section{Introduction}

The added value of brand to product and its importance have been mentioned since late 80's(Farquhar, 1989;:Leuthesser, 1988).Early research brought forth the issue more than thirty years ago and it is still the core indicator for the marketing of a brand while customers are key stakeholders. In 1990's Aaker (1991) andKeller (1993, 1998) made valid contributions to the concept and the other academic researchers supported the competitive advantage of creating strong brand and successful brand management (Srivastava and Shocker, 1991; Kapferer, 1997; Lassar et al.1995).Aaker (1991) defines consumer based brand equity concept as "a set of brand assets and liabilities linked to a brand, its name, and symbol that add to or sub-tract from the value provided by a product or service to a firmand/or to that firm's customers" (Aaker, 1991:15). Keller (1993) explained customer-based brand equity as "the differential effect of brand knowledge on consumer response to the marketing of the brand" (Keller, 1993:2)

As the brand equity has a crucial role for competitive advantage (Aaker, 1991; Srivastava and Shocker,1991;Farquhar, 1989; Keller, 1993), the force majeure events should be taken into consideration not to affectthat invaluableasset (Ambler, 2003) negatively. Since Covid-19 has appeared suddenly in the beginning of 2020, the companies all over the world gave alert to handle this unknown situation without any harm to their brand. In normal circumstances, global brands competition is announced ever year via sources like Nielsen, Forbes etc. as competitive advantage is the main goal for the companies to be survival and sustainable. In this unexpected situation, many brands support the campaigns of relief efforts for Covid-19 and this decent behavior will automatically take place in the customer perception.

In Turkey, according to pandemic precautions, youth under 20 had to stay at home more than 2 months in April and May 2020. It is assumed to that they are affected by the period both psychologically and physically. In these boring time, young consumers could have tendency to increase the consumption of snacks, especially chips while hanging out at home as chips make joy for consumption. Therefore, we thought that it will be a good period to make observation as especially target market of chips sector is mostly young consumers. Moreover, in the study of Prime (2020), Covid-19 social responsibility campaigns and brand contributions in Turkey are listed. According to that report, many sectors like FMCG, fast food, telecommunication, e-trade and social media supported Covid-19 precautions and donations. This sensitive approach of FMCG sector can be evaluated as right time to make an evaluation for brand equity. Although many other researches measure the brand equity among different sectors like hotels (Zhou and Jiang, 2011) or restaurants (Majid et al. 2013; Kim and Kim, 2004), there is a gap in the literature on snack sector. Aaker (1991) mentions that the brand equity is able to show difference in nature according to sectors and should be evaluated under each sector determinants. 
The main purpose of this paper is to investigate the effects of brand awareness, brand image, brand loyalty and perceived quality to brand equity among PepsiCo's Frito Laychips. Chips market is among fast growing markets in Turkey in 5 years. Per capita consumption is nearly $1 \mathrm{~kg} /$ year, and 15-24 age group is the consumers at first place (Aksel, 2018).

In the study, brand equity is measured under Aaker's CBBE approach. It is aimed to contribute to the literature by searching especially during these unexpected days and later make a cross-check study to make a comparison. It is predicted that Covid-19 effect make revaluations in many sectors by socially and economic. The results are beneficial in managerial side as it is crucial to follow the customers behaviors in focus and determine the marketing decisions according to that consequences. As social media becomes an instrument recently where consumers and marketers can reach intelligence in synchronized and directly, we ask the questioners to take into social media account while evaluating the survey and to reach accurate outcomes.

The organization of paper is as follows, related literature is presented briefly in the next section and then the hypothetical model designed, and hypotheses are introduced. In methodology section, the data and analyses are given detailed. In conclusion side, the findings of the research is discussed. Furthermore, the limitations and implications of the study are presented together with the suggestion for future research.

\section{Literature Review}

Keller (2004) identified the success of a brand as meeting the customer's needs as the customers perceive the brand value according to their satisfaction. This successful approach is theorized as brand equity (Randall, 2000).

When the term is first introduced, Keller (1993) stated that brand equity approach is evaluated through customer perspective or organizational influence. By years, academic researchers tend to former approach towards the understanding of brand equity(Aaker, 1991; Keller 1993; Yoo and Donthu; 1997, 2001; Kim et al. 2003) In this paper, we focus on the consumer side of brand equity as stated customer-based brand equity (Keller, 1993).

Aaker (1991) determines dimensions measuring brand equity as brand loyalty, brand awareness, perceived quality and brand association. These four dimensions defined by Aaker (1991) have been accepted in the literature merged in CBBE approach and other researchers have supported it to be valid for brand equity measurement (Aaker, 1991; Keller 1993; Yoo and Donthu,1997, 2001; Kim et al. 2003.Keller (1993) explains this approach as it is appeared when a strong awareness and familiarity to brand association are occurred in memory of the customer (Keller 2008).

The fifth brand asset was described by Aaker as other property asset including the patents, trademark and copyright. This asset is not accepted as a dimension to measure brand equity under consumer-based brand equity (CBBE) and found irrelevant to customer orientation approach(Yoo and Donthu, 1997;Lu and Xie, 2000; Kim et al.2008; Washburn and Plank, 2002; Yoo and Donthu, 2001).

However various researchers put forth at least one of these dimensions linked to brand equity based on CBBE model. (Keller 1993, 2008; Zeithaml, 1998; Kim and Kim, 2004;Yooet al. 2000;Yoo and Donthu; 2001, Kim et al. 2003, Oliver; 1997; Washburn and Plank 2002). Keller (2008, p. 53) also mentions the link between dimensions under CBBE as "when the consumer has a high level of awareness and familiarity with the brand and holds some strong, favorable, and unique brand associations in memory."

Financial techniques (Farquhar et al. 1991; Simon and Sullivan 1990;Swait et al. 1993;Kapferer 1997) arealso used to measure brand equity. In financial perspective, the market value of company asset is taken into consideration (Farquhar et al. 1991; Simon and Sullivan 1993; Swait et al. 1993;Kapferer 1997). However, in the customer-based brand equity approach, brand equity is feed by the brand name that is called the consumer's response regarding brand knowledge to that brand (Keller, 1993; 2008)

Brand awareness has a crucial place to stimulate the consumer when they first meet each other. Therefore, for new products, it is more difficult to arrange and manage it in the beginning. According to the order of the concepts, after brand awareness, brand associations and then brand loyalty are occurred (Washburn and Plank 2002).Brand association is defined "as any link in memory to a brand" by Aaker (1991:109). Brand extension is also developing according to brand association (Aaker, 1991; Keller, 1993) as the customers get used to purchase the same product again and again. According to Kim and Kim (2004) brand image is also a dimension of brand equity as Aaker (1996) brought up the brand association being subset of brand image. This attitude can be influenced by the refence groups as brand image is called social image (Lassar et al. 1995). In this study, brand image is replaced with brand association as brand image is found more inclusive. 
Aaker $(1991 ; 39)$ defines brand loyalty as "the attachment that a customer has to a brand" as this attitude explains the strong feelings and passion of the customer for that brand. Brand loyalty is very important asset for the brands compared to other brands and it can be accepted as an invisible gun used for competitors. Keller (1993) also defines brand loyalty in cognitive and behavioral side. When the customer chooses that brand in first, it becomes a cognitive loyalty. On the other hand, when the brand is purchased repeatedly, according to cognitive loyalty, it turns to behavioral loyalty. Cognitive loyalty is accepted as highest level of brand awareness (Keller, 1993) as "the strength of a brand's presence in the consumer's mind" Aaker (1991).

Perceived quality is accepted as another dimension of brand equity and not a subset of brand association (Aaker, 1991) this separate dimension is the judgement of the consumer about the brand (Konecnik, 2006) therefore it can be positive or negative. This results that whether the brand awareness or association are strong, it doesn't mean that perceived quality would be high either.

\section{Hypotheses and the Model}

According to the literature review, the theoretical model is designed, and the hypotheses are presented below. As the main investigation in this research is to examine the relationship between the brand equity dimensions and brand equity, also to measure the strength and direction of the effect of dimensions to brand equity. In this manner, the independent variables are defined as brand awareness, brand image, brand loyalty and perceived quality as far as the dependent variable is determined as brand equity. Hypotheses are listed below, and hypotheticalresearch model is drawn in Figure.1.

\section{Figures}

Figure 1. Hypothetical Research Model

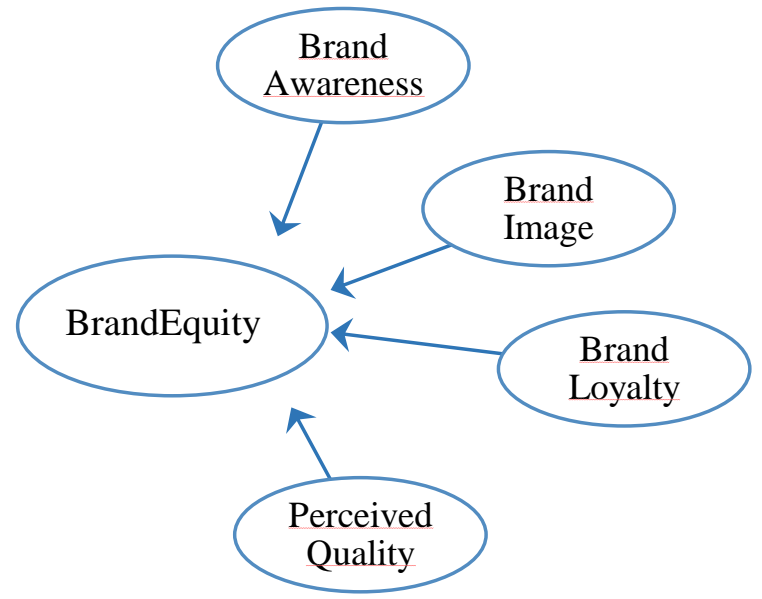

$\mathbf{H}_{\mathbf{1}}$ : Brand awareness has a positive and meaningful effect on brand equity

$\mathbf{H}_{2}$ : Brand image has a positive and meaningful effect on brand equity.

$\mathbf{H}_{3}$ :Brand loyalty has a positive and meaningful effect on brand equity.

$\mathbf{H}_{4}$ : Perceived quality has a positive and meaningful effect on brand equity

\section{Methodology}

\subsection{Research Methodology}

In this study, data was collected from OSTIM Technical University students as their ages are among the highest chips consumers. Questionnaires are applied through the online survey method within 20 days period on June 2020 after the release of Covid-19 Stay at Home precaution. There is a total of 248 students in the university from Faculty of Engineering, Faculty of Economics and Administrative Sciences and Vocational High School. 124 participant's surveys are subject to the analysis without any mistakes and deficiencies. This sample size is considered suitable regarding 30-500 sample sizes stated by Roscoe (1975). The sample of the research consists of young consumers who frequently use social media as well. 
The questionnaire was designed and separated into two parts. In first part, the questionnaire data and information that related to the respondents were elaborated, such as gender, age, department, favorite product, money spent for buying this product in one month, frequency of buying this product in one month. Second part consists of measuring effect of brand awareness, brand image, brand loyalty and perceived quality on brand equity.

Items that are being used for measuring brand awareness, brand image, brand loyalty and brand equity were adopted from Sasmita and Suki (2015)'s study that developed a measurement adapted to social media items. The measurement items of perceived quality were adopted from Kim and Kim (2005). Five-point likert scales were used between "I strongly disagree" (1) and "I strongly agree" (5) for the measurement of all variables. The survey results obtained were analyzed with SPSS 22 package software and the analysis results were evaluated.

\subsection{Analysis and Results}

\subsubsection{Demographic Profile Analysis}

In this survey consist of 70,2 percent male and 29,8 percent female responders. It is seen from Table. 1 that the students participating in the research are mostly between the ages of 18-25.

It was concluded that the students preferred Doritos most with the rate of $43.5 \%$ and secondly, Lay's with the rate of $25.8 \%$. The least preferred products of the participants are Çerezza and Cheetos with 2,4\%. When the frequency of purchasing from FritoLay products in one month is evaluated, it was concluded that chipsare purchased 4-6 times at most with a ratio of 64.9 .

The amount of money that most of the participants $(50,8 \%)$ spend to buy this product range between 6-15 TL. Further, $51 \%$ of the students participating in the survey have monthly individual income in the range of 1001-1500 TL.

Tables

Table 1. Demographic Data

\begin{tabular}{|c|c|c|c|c|c|}
\hline & Frec & $\%$ & & Frequency & $\%$ \\
\hline Gender & & & Age & & \\
\hline Man & 87 & 70,2 & $18-25$ & 115 & 92,7 \\
\hline Woman & 37 & 29,8 & $22-25$ & 5 & 4 \\
\hline Individual Income $(T L)$ & & & $26+$ & 4 & 3,2 \\
\hline $0-500$ & 29 & 30,9 & $\begin{array}{l}\text { Frequency of buying this product in } \\
\text { one month }\end{array}$ & & \\
\hline $501-1000$ & 2 & 2,1 & $1-3$ & 20 & 21,3 \\
\hline $1001-1500$ & 48 & 51,1 & $4-6$ & 61 & 64,9 \\
\hline $1501+$ & 4 & 4,3 & $7-9$ & 13 & 13,8 \\
\hline Favorite Product & & & $10+$ & 4 & 3,2 \\
\hline Doritos & 54 & 43,5 & $\begin{array}{l}\text { Money spent for buying this } \\
\text { product in one month }(T L)\end{array}$ & & \\
\hline Lay’s & 32 & 25,8 & 5 and less & 32 & 25,8 \\
\hline Ruffles & 27 & 21,8 & $6-15$ & 63 & 50,8 \\
\hline Other & 5 & 4 & $16-30$ & 22 & 17,7 \\
\hline Cheetos & 3 & 2,4 & $31-50$ & 3 & 2,4 \\
\hline Çerezza & 3 & 2,4 & $50+$ & 3 & 2,4 \\
\hline Total & 124 & 100 & \begin{tabular}{|l} 
Total \\
\end{tabular} & 124 & 100 \\
\hline
\end{tabular}

\subsubsection{Reliability analysis}

Reliability analysis was performed to measure the internal consistency of the scales. The alpha value, which is generally not expected to fall below 0.60 , ranges from 0.60 to 0.85 .

\subsubsection{Correlation Analysis}

Correlation analysis were performed to check the correlation between the variables (i.e. brand awareness, brand image, brand loyalty, perceived quality, and brand equity).According to Table.2, the inter-correlations between brand awareness, brand image, brand loyalty, and perceived quality with the brand equity are significant at the 0.01 level and are positively correlated, ranging 0.308 to 0.607 . 
Brand image having the strongest correlation with brand equity, followed by brand loyalty $(\mathrm{r}=0.536, \mathrm{p}<0.01)$, brand awareness $(\mathrm{r}=0.529, \mathrm{p}<0.01)$ and perceived quality that having the lowest correlation $(\mathrm{r}=0.440, \mathrm{p}<0.01)$. Thus, there is no multicollinearity problem detected in this research.

When we consider the findings of the correlation analysis, it is possible to mention that there is a positive and significant relationship between brand value and brand loyalty, image, awareness and perceived quality.

Table 2. Correlation analysis

\begin{tabular}{|l|llllll|}
\cline { 2 - 7 } \multicolumn{1}{c|}{} & Mean & SD & $\mathbf{1}$ & $\mathbf{2}$ & $\mathbf{3}$ & $\mathbf{4}$ \\
\hline Variables & & & & & & \\
Brand awareness & 3.7242 & 0.823 & 1 & & \\
Brand limage & 3.6532 & 0.659 & $.526^{* *}$ & 1 & & \\
Perceivedquality & 3.1694 & 0.703 & $.448^{* *}$ & $.411^{* *}$ & 1 & \\
Brand equity & 3.1532 & 1.064 & $.308^{* *}$ & $.381^{* *}$ & $.333^{* *}$ & 1 \\
\hline
\end{tabular}

Note: $* * p<0.01$

\subsubsection{Regression Analysis}

In this study, the effect of brand awareness, brand image, brand loyalty and perceived quality on brand equity is examined via multiple regression analysis as the analysis results are listed in Table.3.

Table 3. Effects of brand awareness, brand image, brand loyalty and perceived quality on brand equity ( $n=124)$

\begin{tabular}{|l|lllllll|}
\hline HYPOTHESIS & $\begin{array}{l}\text { Std. } \\
\text { Coef. }(\boldsymbol{\beta})\end{array}$ & $\begin{array}{l}\text { Std. } \\
\text { Er. }\end{array}$ & t & Sig. & $\begin{array}{l}\text { Toleran } \\
\text { ce }\end{array}$ & VIF & Cond. \\
\hline $\begin{array}{l}\mathrm{H}_{1} \text { : Brand awareness has a positive effect on } \\
\text { brand equity }\end{array}$ & 0.195 & 0.082 & 2.252 & $0.026^{*}$ & 0.546 & 1.830 & ACCEPTED \\
$\begin{array}{l}\mathrm{H}_{2} \text { : Brand image has a positive effect on brand } \\
\text { equity. }\end{array}$ & 0.351 & 0.098 & 4.218 & $0.000^{* *}$ & 0.594 & 1.684 & $A C C E P T E D$ \\
$\begin{array}{l}\mathrm{H}_{3} \text { : Brand loyalty has a positive effect on brand } \\
\text { equity. }\end{array}$ & 0.268 & 0.087 & 3.407 & $0.001^{* *}$ & 0.664 & 1.506 & ACCEPTED \\
$\begin{array}{l}\mathrm{H}_{4} \text { : Perceived quality has a positive effect on } \\
\text { brand equity }\end{array}$ & 0.172 & 0.053 & 2.399 & $0.018^{*}$ & 0.796 & 1.256 & ACCEPTED \\
\hline
\end{tabular}

$R^{2}: 0.516$, Adjusted $R^{2}: 0.496, F: 25.168$ with $p=0.000,{ }^{*} p<0.05$, ** $p<0.01$

Multiple regressions were analyzed between the brand value included as the dependent variable and the brand relationship, brand loyalty, brand awareness and brand image, which are independent variables.However, brand loyalty, brand image, brand awareness, and perceived quality have a significant impact on brand equity. The corrected $\mathrm{R}^{2}$ of 0.49 indicates that independent variables explain 49 percent of the variance of the dependent variable and $F$ value of 25.168 is significant at 0.001 , and this is considered favorable for the model's suitability and compliance with the data collected.So, $\mathrm{H}_{1}, \mathrm{H}_{2}, \mathrm{H}_{3}$ and $\mathrm{H}_{4}(\beta=.195, \mathrm{p}<0.001 ; \beta=.351, \mathrm{p}<0.00 ; \beta=.298, \mathrm{p}<0.026 ; \beta=.172, \mathrm{p}<0.018)$ hypotheses were accepted. Based on Table 2, the highest standardized $\beta$ coefficient appeared for brand image, followed by brand loyalty, brand awareness, and perceived quality, respectively.

\section{Discussion \&Conclusion}

Our study has conclusion based in both theoretical and managerial implications. In terms of results, it is obtained that there is a positive relationship between brand equity and brand equity dimensions as brand awareness, brand image, brand loyalty and perceived quality. The results support the study of Sasmita and Suki (2015) examining young consumers' insight on brand equity in Malaysia. Brand image has the highest score effecting brand equity as it can be related that among young consumers, image is important then everything. Regarding that social groups effect the decision of each other's purchasing behavior especially in young consumers Norazah and Norbayah (2013).

Norazah and Norbayah (2013) also stated that social media is an important channel to reach the young consumers and make a connection to them. The other next step is to turn these consumers to loyal customers where brand loyalty occurs (Huify, 2016;Hubspot 2016). 
Brand awareness is assumed to have the highest effect on brand equity as it is in the study of Sasmita and Suki (2015) however it became after brand loyalty. In theoretical background, brand awareness is accepted in the first step for potential customers to start the first move of the relationship with brand (Washburn and Plank 2002). Perceived quality is defined as the dimension of brand equity, as it is also supported in our research as well. Although, it can be separate (Konecnik, 2006) then the other dimensions, it has a positive effect on brand equity for young consumers' insight.

For brand managers, our investigation stated that social media has a crucial place to get in touch with potential customers. Therefore, they should take into consideration all different social media channels, especially Facebook, Instagram and Twitter. Brand equity dimensions are stated that the brand managers should take into consideration to develop their marketing strategies for gaining competitive advantage. As the relationship and interaction with customers has direct effect to have more valuable brand equity, the dimensions should be analyzed detailed. Customer oriented brand equity (Aaker, 1991; Keller, 1993) results to customer focused market orientation which has a superior value for the customers (Narver et.al, 2004).

In our research, the sample size can be accepted as a limitation as it is the first facility year of OSTIM Technical University, and the overall population is low. According to the whole number of students, only half of them made a useful feedback. Also, we focus on only chips of FritoLay however there are local snacks among Turkish brands. We choose this joyful consumption good within Covid-19 Days, especially the highest consumer of the product had to stay at home under Turkish Law obligations.

For further studies, the sectors can be expanded and also make comparative research. Also, international students can contribute to the research as cultural attitudes differ and their preferences may affect the brand equity perception. To improve and generalize the findings of the study, different sampling techniques can be applied with larger sampling size.

\section{References:}

Aaker, D. A. (1991). Managing Brand Equity: Capitalizing on the Value of Brand Name. New York: The Free Press.

Aaker, D. (1996). Measuring brand equity across products and markets. California Management Review, 38(3), 102120.

Aksel, E. (2018). Frito Lay Türkiye. (G. Hatt1, Interviewer) Retrieved from GidaHatt1: https://www.gidahatti.com/fritolay-tuerkiye-genel-mueduerue-ece-aksel-2-38577/

Ambler, T. (2003). Marketing and the Bottom Line: The Marketing Metrics to Pump Up Cash Flow. New York: FT Prentice Hall, Second Edition.

Farquhar, P. H. (1989). Managing brand equity. Marketing Research, 24-33.

Farquhar, P. H., Han, J. Y., \&Ijiri, Y. (1991). Recognizing and measuring brand assets. Cambridge: Marketing Science Institute.

Hubspot. (2016). The Inbound Methodology - The best way to turn strangers into customers and promoters of your business. Retrieved from http://www.hubspot.com/inbound-marketing

Huify. (2016). Inbound Methodolgy - Turn strangers into customers, and then promoters of your business. Retrieved from https://www.huify.com/inbound-marketing

Kapferer, J.-N. (1997). Managing Luxury Brands. Journal of Brand Management, 251-259.

Keller, K. L., Heckler, S. E., \& Houston, M. J. (1988). The Effects of Brand Name Suggestiveness on Advertising Recall. Journal of Marketing, 62(1), 48-57.

Keller, L. L. (1993). Conceptualizing, Measuring, and Managing Customer-Based Brand Equity. Journal of Marketing. 57(1), 1-22.

Keller, K. L., \&Ailawadi, K. L. (2004). Understanding retail branding: conceptual insights and research priorities. Journal of Retailing, 331-342.

Keller, K. L. (2008). Strategic Brand Management: Building, Measuring, and Managing Brand Equity . Upper Saddle River, NJ,: Pearson Prentice-Hall.

Kim, H.-b., Kim, W. G., \& An, J. A. (2003). The effect of consumer-based brand equity on firms' financial performance. Journal of Consumer Marketing, 335-351.

Kim, W. G., \& Kim, H.-G. (2004). Measuring Customer-Based Restaurant Brand Equity. Cornell Hotel and Restaurant Administration Quarterly, 45(2), 115-131.

Kim, H. B., \& Kim, W. G. (2005). The relationship between brand equity and firm's performance in luxury hotels. Tourism Management, 26(1), 549-560.

Kim, W. G., Jin-Sun, B., \& Kim, H. J. (2008). Multidimensional customer-based brand equity and its consequences in midpriced hotels. Journal of Hospitality \& Tourism Research, 32(2), 235-254. 
Konecnik, M. (2006). Croatian-based brand equity for Slovenia as a tourism destination. Economic and Business Review for Central and South, 8(1), 83-108.

Lassar, W., Mittal, B., \& Sharma, A. (1995). Measuring customer-based brand equity . Journal of Consumer Marketing, 11-19.

Leuthesser, L. (1988). Defining, measuring, and managing brand equity: A conference summary. Marketing Science Institute, 88-104.

Lu, H., \&Xie, Y. W. (2000). A study on the relationship between customer satisfaction, brand equity, and customer lifelong value. Chung Yuan Journal 28(2), 31-41.

Majid, M. A., Chik, C. T., Alias, M. A., \&Samsudin, A. (2016). Assessing customer-based brand equity theory on repurchase intention in the family restaurant. Procedia Economics and Finance, 183-189.

Narver, J. C., Slater, S. F., \& MacLachlan, D. L. (2004). Responsive and Proactive Market Orientation and New-Product Success. The Journal of Product Innovation Management, 334-347.

Norazah, M. S., \&Norbayah, M. S. (2013). Dependency on Smartphones: An Analysis of Structural Equation Modelling. JurnalTeknologi (Social Sciences), 62(1), 49-55.

Oliver, L. R. (1997). Satisfaction: A behavioral perspective on the consumer. New York: McGraw-Hill.

Randall, G. (2000). Branding: A Practical Guide to Planning Your Strategy. London: Kogan Page, Second Edition.

Roscoe, J. T. (1975). Fundamental Research Statistics for the Behavioral Sciences. New York: Holt Rinehart \& Winston, Second Edition.

Sasmita, J., \& Suki, N. M. (2015). Young consumers' insights on brand equity. International Journal of Retail \& Distribution Management, 43(3), 276-292.

Simon, C. J., \& Sullivan, M. W. (1990). The measurement and determinants of brand equity: A financial approach. University of Chicago: Working Paper, Graduate School of Business.

Srivastava, R. K., \& Shocker, A. D. (1991). Brand Equity: A Perspective on its Meaning and Measurement. Cambridge: Marketing Science Institute.

Swait, J., Erdem, T., Louviere, J., \&Dubelaa, C. (1993). The equalization price: A measure of consumer-perceived brand equity. International Journal of Research in Marketing, 23-45.

Washburn, J. H., \& Plank, R. E. (2002). Measuring Brand Equity: An Evaluation of a Consumer-Based Brand Equity Scale. Journal of Marketing Theory and Practice, 46-62.

Yoo, B., \&Donthu, N. (1997). Developing and validating a consumer-based overall brand equity scale for Americans and Koreans: An extension of Aakers and Kellers conceptualizations. Proceedings Ama Summer Educators Conference. Chicago: American Marketing Associations.

Yoo, B., Donthu, N., \& Lee, S. (2000). An examination of selected marketing mix elements and brand equity. Journal of the Academy of Marketing Science, 28(2), 195-211.

Yoo, B., \&Donthu, N. (2001). Developing and validating a multidimensional consumer-based brand equity scale. Journal of Business Research, 1-14.

Zeithaml, V. (1998). Consumer perception of price, quality and the value: A mean-end and synthesis of evidence. Journal of Marketing 52(2), 2-22.

Zhou, Y., \& Jiang, J. (2011). The Impacts of Customer-Based Brand Equity on Revisit Intentions: An Empirical Study on Business and Leisure Traveler at Five Shanghai Budget Hotels. Research Journal of International Studies, 110-119. 